\title{
Good Corporate Governance and Financial Performance on Capital Adequacy Ratio: A Reflection of Indonesian Conventional Banking
}

\author{
Yuli Agustina ${ }^{1}$, Agung Winarno ${ }^{2}$, Ariska Dyan ${ }^{3}$ \\ ${ }^{1,2}$ Faculty of Economics, Universitas Negeri Malang, Indonesia \\ *Corresponding author. Email: yuli.agustina.fe@um.ac.id
}

The purpose of this study is to determine the impact of good corporate governance, as well as financial performance as measured by non-performing loans, net interest margin, return on assets, and loan to deposit ratios, on the capital adequacy ratio of conventional banking in the period 2015-2019, using data from the Federal Reserve. The composite value of banking self-assessment is the indicator that was utilized to determine good corporate governance in the context of this study. The quantitative approach used in this study was combined with secondary data. Purposive sampling was used in this study to select a sample of 35 banks, which was then analyzed. The findings revealed that GCG, NPL, ROA, and LDR had no impact on CAR. This occurs because the revenues obtained by the bank are used to mitigate the bank's operational risk, and so have no effect on the bank's capital adequacy ratio (CAR). The NIM has a negative and statistically significant effect on the CAR. This is due to the fact that the NIM indicates that the quantity of loans granted is increasing, implying that the risk faced by the bank is also increasing.

OPEN ACCESS

ISSN 2528-4649 (online)

Keywords: GCG, NPL, NIM, ROA, LDR, CAR

ISSN 2338-4409 (print)

Reviewedby:

Zarah Puspitaningtyas, Irwan Moridu

${ }^{*}$ Correspondence: Yuli Agustina yuli.agustina.fe@um.ac.id Received: May 30, 2021

Accepted: August 19, 2021

Published: September 27, 2021

JBMP: Jurnal Bisnis, Manajemen dan

Perbankan.

Vol: $7 /$ No. 2

doi: 10.21070/jbmp.v7vi2.1542 


\section{INTRODUCTION}

The contribution of banking sector also makes a significant contribution in accommodating the needs of the community related to finance, both in financing activities and resource activities. Commercial Banks are defined by Law No. 10 of 1998 as banks that conduct payment traffic services in a conventional manner and/or according to sharia principles. According to Riyadi (2006:22), the bank's capital adequacy and liquidity level must be the primary focus of interest when conducting business, since they have a significant impact on the bank's operating activities. According to Darmawi (2014: 57), the Bank can offer cash to meet its customers' needs by ensuring the stability of its capital and liquidity.

Capital adequacy ratio is a ratio that indicates a business's ability to absorb losses caused by risks associated with business activities. According to Anjani \& Purnawati (2014), a bank's Capital Adequacy Ratio might indicate how well or poorly it manages its capital. According to Bank Indonesia Regulation No. 15/12/PBI/2013, each bank is required to maintain a minimum capital ratio of $8 \%$ of weighted activation, as determined by the Capital Adequacy Ratio. If the bank's Capital Adequacy Ratio is less than $8 \%$, the bank is in poor state and at risk of liquidation. The increase in the Capital Adequacy Ratio's value also increases the bank's risk exposure.

Banks are exposed to non-performing loans as a result of the debtor's failure to repay credit commitments. When the amount of non-performing loans exceeds the total loans owned by the bank, the bank's quality is considered to be devastating. This demonstrates the bank's inability to manage credit optimally. According to Bank Indonesia Regulation No. 11/25/PBI/2009, a bank's maximum exposure to non-performing loans is $5 \%$ of total credit. Darmawi (2014:61) defines the Loan to Deposit Ratio as a measure of banking liquidity risk. The Loan to Deposit Ratio is a ratio that compares the total loans made to the total income received from third parties. The higher the Loan to Deposit Ratio, the more debts remain unpaid. Kasmir (2014:225) states that the safe range for achieving a bank's Loan to Deposit Ratio is between 80 and 110 percent.

According to Harahap (2010:305), profitability can be defined as the ability of financial institutions to maximize their existing resources in order to achieve their business objectives. When it comes to fulfilling its objectives, profitability is one of the variables that demonstrate the success and efficiency of the banking industry. Return on Assets and Net Interest Margin are two metrics that can be used to determine profitability. According to Kasmir (2014: 201), return on assets can be used to characterize a bank's ability to make profits by utilizing its assets to produce revenue. Based on the research conducted by Riyadi (2006), the ability of banks to manage productive assets in order to generate net interest revenue can be described by the term "Net Interest Margin." Thus according Rianto and Salim (2020), the higher the profitability of a bank (as measured by Return on Assets and Net Interest Margin), the better the management of banking assets in terms of making a profit is performed (profit).

One of the benefits of Good Corporate Governance for banking stakeholders is the fulfillment of commitments by banking management to shareholders and other stakeholders, which is one of the obligations that banking management has to them. According to Lestari et al (2018), successful implementation of Good Company Governance has the potential to boost the efficiency with which capital is used to generate corporate profits. As per Tumewu and Alexander (2013), excellent corporate governance plays a significant role in garnering loyalty from the wider community and is one of the most critical factors in the establishment of a strong and healthy financial institution. On the basis of this description, the purpose of this study is to determine the relationship between the implementation of Good Corporate Governance and financial performance, as measured by nonperforming loans, net interest margin, loan-to-deposit ratios, and return on assets in the capital adequacy ratio of conventional banking in Indonesia between 2015 and 2019.

\section{LITERATURE REVIEW}

Agency theory is a notion that explains the nature of the relationship between an agent and a principal's representative. Jensen and Meckling argue in Triyuwono (2018) that agents and principals are both parties with individual interests, and that the behavior of agents who act in a way that differs from the expectations of the principal is considered to be a normal action motivated by the desire to fulfill personal desires. Because the agent has more information than the principal, the relationship between the agent and the principal can result in information asymmetry. This condition is the result of the granting of authority to the agent to be directly responsible for the course of operational activities, which has the effect of increasing information asymmetry. It is possible that this scenario could result in agency issues because the information provided by the agent to the principal will not be transparent.

The Capital Adequacy Ratio (CAR) is a ratio that can be used to determine a company's potential to withstand losses caused by risks associated with its business operations. According to Wardiah (2013: 295), the Capital Adequacy Number is a ratio that indicates a bank's ability to cover risks that may arise as a result of its operational activities, such as nonperforming loans. Based on the research of Fauzi et al. (2020), the Capital Adequacy Ratio is an indicator that measures the capacity of a bank's ability to deal with the operational risks that banks confront. According to Darmawi (2014: 57), the Bank is able to offer cash to meet the needs of its clients by preserving capital stability and liquidity levels.

"Good Corporate Governance" (GCG) refers to the collection of systems that constitute the foundation of a company's management mechanism and are used to define the direction of the organization's performance. To anticipate agency difficulties that may arise from the relationship between the principal and the agent, it is necessary to have Good Corporate Governance practices in place. The establishment of Good Corporate Governance, according to 
Arifin (2005:47), can ensure that the delegation of authority carried out by the principal to the agent is successful and that the misuse of power by the agent is kept to a minimum.

The non-performing loan (NPL) ratio is a measure of the relationship between non-performing loans and the total amount of loans given by banks. Repi and colleagues (2016) define corporate risk as a divergence from something that is expected to be uncertain as a result of internal and external factors that affect a company's operations. A rise in nonperforming loans at financial institutions, according to Purwanto (2011:167), will result in a decline in banking revenues and profits. As a result, improvements in the management of the risk of non-performing loans in banks are required in order for the level of Non-Performing Loans (NPL) to remain below the safe limit established by Bank Indonesia.

The loan-to-deposit ratio (LDR) is a comparison between the entire amount of loans made and the total amount of income received from outside sources. According to Putri and Dana (2018), the Loan to Deposit Ratio is a financial liquidity indicator used in banks to assess their financial health. The higher the loan-to-deposit ratio of a bank, the weaker the bank's ability to maintain liquidity. According to Rianto and Salim (2020), the increase in the acquisition of bank shares has been on the rise. It is evident from the Loans to Deposits ratio that banks have disbursed more credit than has been obtained from the community, demonstrating that youngsters do not have a well-functioning credit management mechanism in place.

The Return on Assets (ROA) ratio is one of the profitability ratios that may be used to determine a company's capacity to manage assets in order to generate profits. It has been argued that the larger the return on assets achieved by a bank, the greater the profit realized by that bank (Rianto \& Salim 2020). According to Putri and Dana (2018), the high or low return on assets of a bank is a measure of the performance of a bank in accomplishing its business objectives in terms of profitability. The return on assets of banks, according to Hengkeng et al (2018), can be used to attract investors by allowing them to determine the potential for profit generation by the bank in question.

The Net Interest Margin (NIM) of a corporation is the net interest income earned on the assets that are managed by the organization. According to Hengkeng et al (2018), unchecked Net Interest Margin growth might have a negative impact on the high or poor profitability of the banking industry. Generally speaking, the larger the value of a bank's net interest margin, the bigger the amount of additional profit the bank earns. According to Dewi and Yadnya (2018), the amount of interest income generated by a bank's Net Interest Margin can be used as a source of additional bank capital to supplement the bank's existing capital.

\section{METHOD (FOR RESEARCH ARTICLE)}

Using secondary data and a quantitative technique, this study examined 48 different banks as a research population. Purposive sampling was the technique that was employed in this investigation. Listed on the Indonesian Stock Exchange between 2015 and 2019, the research sample criteria included conventional and non-Islamic banks that undertake assessments linked to Good Corporate Governance, and that were part of the research sample. Based on these criteria, the sample for this study consisted of 35 banks, for a total sample size of 175 data points. The multiple linear regression technique was used in this study, which is an analytical test technique. The standard assumption tests, such as the normality test, multicollinearity test, heteroscedasticity test, and autocorrelation test, were used in the hypothesis testing technique. While this is taking place, the study model employed a threshold of significance of $10 \%$, or 0.10 .

[Figure 1 about here.]

\section{RESULTS AND DISCUSSION}

\section{Results}

In order to assess if the data under investigation has been normally distributed or not, the normality test was used. According to Priyatno (2017: 85), the normality test is one of the conditions that must be met before a parametric analysis can be performed. Because the significance value obtained from the One-Sample Kolmogorov-Smirnov test was greater than 0.1 , the normality assumption in this study was declared fulfilled, and it can be concluded that the data from the regression model was normally distributed, as demonstrated by the results of the analysis.

\section{[Table 1 about here.]}

According to Ghozali (2016:107), the autocorrelation test is used to determine whether there is a correlation between the confounding error (error) in the current period ( $t$ ) and the confounding error (error) in the preceding period ( $\mathrm{t}$ ) in a linear regression model ( $\mathrm{t}-1)$. The Durbin-Watson test can be used to perform an autocorrelation analysis (DW test). Based on the findings of the investigation, the Durbin-Watson value ranges between $\mathrm{Du}$ and 4-dL, and it can be stated that the regression model does not have a link with the data. Table 1 shows the results of the normality and autocorrelation tests, as well as the overall results.

\section{[Table 2 about here.]}

The multicollinearity test was used to examine whether or not there is a correlation between the study's independent variables. According to Priyatno (2017: 120), one technique to determine if two independent variables are multicollinear is to examine the value of the Variance Inflation Factor (VIF). The VIF value for each independent variable in the study was determined to be ten using the analysis results. 
Thus, the regression model does not exhibit multicollinearity between the independent variables.

The heteroscedasticity test was used to examine whether there was an inconsistency between the independent variable's significance value and the absolute value of the residual in a regression model. According to Ghozali (2018:135), the heteroscedasticity test can be performed using the Glejser test results. According to the Glejser test results, a significance level of 0.10 was attained, indicating that the heteroscedasticity test in this study was satisfied, implying that all independent variables employed in the investigation were homoscedastic. Table 2 contains the results of the Multicollinearity and Heteroscedasticity tests.

\section{[Table 3 about here.]}

The findings of the multiple linear regression equation are as follows, based on data processing using SPPSS version 23 and test conditions of $\mathrm{a}=0.10$ for significance level and t-count 1.645 or t-count -1.645 for t-count. 21.716 $-0.034 \mathrm{NIM}+\mathrm{I} \mathrm{Y}=21.716-0.034 \mathrm{NIM}+\mathrm{I}$ Thus, it can be inferred that four hypotheses were rejected and one was supported in this investigation. Table 3 illustrates hypothesis testing.

With a t-count of $-0.473-1.645$ and a significance level of 0.640 .10 , it is decided that Hypothesis 1 is rejected. These findings imply that effective corporate governance has no effect on the capital adequacy ratio. Thus, a rise or decrease in Good Corporate Governance has no discernible influence on the financial system's acquisition of the Capital Adequacy Ratio.

With a t-count of $-0.825-1.645$ and a significance level of 0.410 .10 , it is decided that Hypothesis 2 is rejected. These findings suggest that Non-Performing Loans have no effect on the Capital Adequacy Ratio. As a result, neither an increase nor a decrease in Non-Performing Loans has a discernible influence on the acquisition of the banking Capital Adequacy Ratio.

With a t-count of $-1.866-1.645$ and a significance level of 0.060 .10 , it is decided that Hypothesis 3 is supported. These findings suggest that the Net Interest Margin has a significant negative impact on the Capital Adequacy Ratio. As a result, an increase in Net Interest Margin has a major impact on the reduction in banking's Capital Adequacy Ratio, and vice versa.

With a t-count of 0.1611 .645 and a significance level of 0.870 .10 , it is decided that Hypothesis 4 is rejected. According to these findings, the Loan to Deposit Ratio has no effect on the Capital Adequacy Ratio. Thus, an increase or decrease in the Loan to Deposit Ratio has no discernible influence on the banking system's acquisition of the Capital Adequacy Ratio.

With a t-count of $-0.729-1.645$ and a significance level of 0.470 .10 , it is decided that Hypothesis 5 is rejected. As a result of these findings, Return on Assets has no effect on the Capital Adequacy Ratio. Thus, an increase or decrease in Return on Assets has no discernible influence on acquiring the banking Capital Adequacy Ratio.

\section{Discussion}

Good corporate governance has a beneficial effect on the capital adequacy ratio

The study's findings indicate that effective corporate governance has no effect on the capital adequacy ratio. The condition of Good Corporate Governance implementation in banking cannot have an effect directly on the bank's capital management system, and therefore has no bearing on the bank's acquisition of the Capital Adequacy Ratio. These findings reinforce study published by Permatasari \& Novitasary (2014), which concluded that the bank's high capital adequacy ratio is a result of suboptimal capital management that is unaffected by Good Corporate Governance standards. These findings contrast with those of Rehman et al. (2010), Chitan (2012), and Prasojo (2015), all of whom assert that good corporate governance has a favorable and significant effect on the capital adequacy ratio.

\section{Non-performing loans have a negative impact on the capital adequacy ratio}

The study's findings indicate that non-performing loans have no impact on a bank's capital adequacy ratio. The acquisition of Non-Performing Loans has no bearing on the effectiveness or ineffectiveness of the bank management's capital management system. This is because the acquisition of Non-Performing Loans and the Capital Adequacy Ratio, which are regulated by Bank Indonesia (the government), are not standardized. These results correspond the findings of Fatra et al. (2020), Sari \& Monica (2016), Margaretha et al. (2015), and Permatasari \& Novitasary (2014), who state that government intervention to maintain a maximum limit of $5 \%$ on Non-Performing Loans is a solution for overcoming bad loans, and thus the ratio of Non-Performing Loans has no effect on the Capital Adequacy Ratio in a bank. These findings contrast with those of Putri \& Dana (2018) and Cahyono \& Anggraeni (2015), who found that nonperforming loans have a positive and statistically significant influence on the capital adequacy ratio. Meanwhile, Hadjixenophontos \& Christodoulou-Volos (2018), Anjani \& Purnawati (2014), Natasia (2014), and Pastory \& Mutaju (2013) concluded that Non-Performing Loans had a considerable negative effect on the Capital Adequacy Ratio.

\section{Effect of Net Interest Margin on Capital Adequacy Ratio.}

According to the study's findings, the Net Interest Margin had a negative and statistically significant effect on the Capital Adequacy Ratio. The increase in Net Interest Margin indicates that more loans are being made to the public; as a result, the danger of defaulting debtors increases, and the Bank's Capital Adequacy Ratio can decline as a result of the increased operational risk burden that bank capital must bear. These findings corroborate Mekonnen's (2015) research, which found that the smaller the bank's Net Interest Margin, the greater the bank's Capital Adequacy Ratio. These findings contrast with those of Thoa and Anh (2017), Dewi and Yadnya (2018), Hengkeng et al. (2018), 
Hadjixenophontos \& Christodoulou-Volos (2018), and Hamidah et al. (2021), who all assert that Net Interest Margin has a positive and significant effect on Capital Adequacy Ratio. Meanwhile, Rianto \& Salim (2020) concluded that the Net Interest Margin had no bearing on the Capital Adequacy Ratio.

\section{Effect of Loan to Deposit Ratio on Capital Adequacy Ratio.}

The Loan to Deposit Ratio has no effect on the Capital Adequacy Ratio, according to the study's findings. The decrease in the Loan to Deposit Ratio suggests that the bank's credit management is improving, resulting in an increase in interest income. However, because the bank's interest revenue is utilized to offset the risk of bad credit, it has no effect on the bank's acquisition of the banking capital adequacy ratio. These results confirm previous research by Putri \& Dana (2018), Fatra et al. (2020), and Sari \& Monica (2016), which concluded that the condition of increasing a bank's Capital Adequacy Ratio is followed by stable loans provided by the bank, such that the Loan to Deposit Ratio gains have no effect on the bank's Capital Adequacy Ratio condition. These findings contrast with those of Hamidah et al. (2021), Rianto \& Salim (2020), and Choerudin et al. (2016), who concluded that the Loan to Deposit Ratio had a substantial negative effect on the Capital Adequacy Ratio.

\section{Effect of Return on Assets on the Capital Adequacy Ratio.}

The study's findings indicate that Return on Assets has no effect on the Capital Adequacy Ratio. Profits earned by the bank through Return On Assets are utilized to manage risks associated with the bank's operational activities, ensuring that return on assets has no effect on the Capital Adequacy Ratio. These results correspond previous studies by Hadjixenophontos \& Christodoulou-Volos (2018), Rianto \& Salim (2020), and Fatra et al. (2020), which concluded that banks' return on assets has no effect on their capital adequacy ratio. These findings contradict those of Cahyono \& Anggraeni (2015), Abiodun et al. (2020), Hengkeng et al. (2018), and Putri \& Dana (2018), who concluded that Return on Assets had a positive and substantial effect on Capital Adequacy Ratio. Meanwhile, Dao \& Nguyen (2020) concluded that Return on Assets had a considerable negative impact on the Capital Adequacy Ratio.

\section{CONCLUSIONS}

According to the findings of the study, good corporate governance has no impact on the capital adequacy ratio of a company. If the implementation of Good Corporate Governance in banking is in poor condition, this will not have a direct impact on the capital management system of the bank. Non-performing loans have no impact on the bank's Capital Adequacy Ratio (CAR). Non-performing loan acquisition and capital adequacy ratio acquisition have been standardized, and each of these measures is supervised by Bank Indonesia (the government) and is distinct from the other. When it comes to the Capital Adequacy Ratio, Net Interest Margin has a negative and statistically significant impact. With increased total credit, comes increased risk of debtor default, and with increased risk of debtor default comes increased burden of operational risk that must be borne by the bank's capital. Neither the Loan to Deposit Ratio nor the Capital Adequacy Ratio have any effect on each other. The increased interest income can be used to offset the risk of bad credit that the bank is exposed to. There is no relationship between Return on Assets and the Capital Adequacy Ratio. It is the bank's profit income received from Return On Assets that is utilized to manage risks originating from the bank's operational activities, resulting in a return on assets that has no impact on the bank's Capital Adequacy Ratio. Furthermore, banks, particularly conventional commercial banks, should be able to optimize credit management and productive assets possessed by them in order to improve and increase the efficiency of their operations. 


\section{REFERENCES}

Abiodun, S. W., Abdul-Azeez, A. A., \& Adewale, Y. L. (2020). Determinants of Capital Adequacy of Nigerian Banks. Market Forces, 15(1), 1-15. https://doi.org/10.51153/mf.v15i1.405

Anjani, D., \& Purnawati, N. (2014). Pengaruh Non-Performing Loans (NPL), Likuiditas dan Rentabilitas Terhadap Rasio Kecukupan Modal. E-Jurnal Manajemen Unud, 3(4), 1140-1155. https://doi.org/10.5771/9783748905929

Arifin, Z. (2005). Teori Keuangan \& Pasar Modal. Yogyakarta: Ekonisia.

Cahyono, H., \& Anggraeni. (2015). Pengaruh likuiditas, kualitas aktiva, sensitivitas pasar, efisiensi, dan profitabilitas terhadap CAR pada bank devisa yang go public. Journal of Business \& Banking, 5(1), 113. https://doi.org/10.14414/jbb.v5i1.476

Chitan, G. (2012). Corporate Governance and Bank Performance in the Romanian Banking Sector. Procedia Economics and Finance, 3(12), 549-554. https://doi.org/10.1016/S2212-5671(12)00194-3

Choerudin, A., Yuniatun, E., \& Kusdiasmo, B. (2016). Pengaruh Non Perfoming Loan (NPL) dan Loan to Deposit Ratio (LDR) terhadap Return on Asset (ROA) dengan Capital Adequacy Ratio (CAR) sebagai Variabel Intervening (Studi Pada Bank Umum yang Terdaftar di BEI Periode Tahun 2012-2015). ProBank, Jurnal Ekonomi Dan Perbankan, 2(2), 28 -47.

Dao, B. T. T., \& Nguyen, K. A. (2020). Bank Capital Adequacy Ratio and Bank Performance in Vietnam: A Simultaneous Equations Framework. The Journal of Asian Finance, Economics and Business, 7(6), 39-46. https://doi.org/10.13106/jafeb.2020.vol7.no6.039

Darmawi, H. (2014). Manajemen Perbankan. PT Bumi Aksara.

Dewi, A. R., \& Yadnya, I. P. (2018). Pengaruh Size, Likuiditas, Risiko Kredit dan Rentabilitas Terhadap Rasio Kecukupan Modal. E-Jurnal Manajemen Universitas Udayana, 7(7), 3502. https://doi.org/10.24843/EJMUNUD.2018.v07.i07.p03

Fatra, S., Mardani, R., \& Wahono, B. (2020). Pengaruh NonPerforming Loan (NPL), Likuiditas, Rentabilitas, dan Efisiensi Operasional Terhadap Rasio Kecukupan Modal (Studi Kasus Pada Perbankan yang Terdaftar di Bursa Efek Indonesia Tahun 2017-2019). Jurnal Ilmiah Riset Manajemen, 9(1), 131-147. http://riset.unisma.ac.id/index.php/jrm/article/view/6955

Fauzi, A., Marundha, A., Setyawan, I., Syarief, F., Harianto, R. A., \& Pramukty, R. (2020). Analisis Capital Adequacy Ratio (CAR) dan Penilaian Tingkat Kesehatan Bank Pada PT. Bank Syariah XXX. JMBI UNSRAT (Jurnal Ilmiah Manajemen Bisnis Dan Inovasi Universitas Sam Ratulangi)., 7(1), 114-127. Dari https://doi.org/10.35794/jmbi.v7i1.28392.

Ghozali, I. (2016). Desain Penelitian Kuantitatif dan Kualitatif untuk Akuntansi, Bisnis dan Ilmu Sosial Lainnya. Yoga Pratama.

Ghozali, I. (2018). Aplikasi Analisis Multivariate Dengan Program IBM SPSS 25 Ed. 9 (9th ed.). Badan Penerbit Universitas Diponegoro.

Hadjixenophontos, A., \& Christodoulou-Volos, C. (2018). Financial Crisis and Capital Adequacy Ratio: A Case Study for Cypriot Commercial Banks. Journal of Applied Finance \& Banking, 8(3), 87-109. http://www.scienpress.com/Upload/JAFB/Vol 8_3_6.pdf

Hamidah, Mahdiyyah, R., \& Mardiyati, U. (2021). Pengaruh NPL, NIM, BOPO, LDR, dan Profitabilitas Terhadap Capital Adequacy Ratio (CAR) Pada Bank Umum Swasta Nasional Devisa di Indonesia Periode 2014 - 2018. Jurnal Riset Manajemen Sains Indonesia (JRMSI), 12(1), 167-190. https://doi.org/doi.org/10.21009/JRMSI.012.1.09

Harahap, S. (2010). Analisis Kritis atas Laporan Keuangan. Rajagrafindo Persada.

Hengkeng, J., Walewangko, E., \& A, N. (2018). Analisis Faktor-Faktor yang Mempengaruhi Capital Adequacy Ratio Bank Sulut-Go Tahun 2002.I - 2017.IV. Jurnal Berkala Ilmiah Efisiensi, 18(4), 84-95.

Kasmir. (2014). Bank dan Lembaga Keuangan lainnya. Rajawali Pers. 
Lestari, L., Chandrarin, G., \& Assih, P. (2018). Effect of Ownership Structure and Corporate Governance to Risk Management and Implications Ontario Banking Performance. IOSR Journal of Business and Management, 20(7), 11-21. https://doi.org/DOI: 10.9790/487X-2007031121

Margaretha, F., Setiyaningrum, D., \& Prasojo, P. (2015). Pengaruh Resiko, Kualitas Manajemen, Ukuran dan Likuiditas Bank terhadap Capital Adequacy Ratio Bank-Bank yang Terdaftar di Bursa Efek Indonesia. Jurnal Akuntansi Dan Keuangan, 13(1), 59-69. https://doi.org/10.9744/jak.13.1.47-56

Mekonnen, Y. (2015). Determinants of Capital Adequacy of Ethiopia Commercial Banks. European Scientific Journal, 11(25), 315-331. https://eujournal.org/index.php/esj/article/view/6222

Natasia, R. (2014). Pengaruh Risiko Kredit, Profitabilitas, Likuiditas, dan Efisiensi Usaha Terhadap Kecukupan Modal Pada Bank Yang Terdaftar Di Bursa Efek Indonesia Periode 2010-2014. Jurnal Akuntansi AKUNESA, 3(3), 1-24.

Pastory, D., \& Mutaju, M. (2013). The Influence of Capital Adequacy on Asset Quality Position of Banks in Tanzania. International Journal of Economics and Finance, 5(2), 179-194. https://doi.org/10.5539/ijef.v5n2p179

Peraturan Bank Indonesia Nomor 11/25/PBI/2009 tentang perubahan atas peraturan Bank Indonesia Nomor 5/8/PBI/2003 tentang Penerapan Manajemen Risiko bagi Bmum. (Online) (https://www.ojk.go.id/id/kanal/perbankan/regulasi/peraturan-bank-indonesia/Pages/peraturan-bank-indonesia-nomor-11-25pbi2009.aspx\#: :text=3.\%20Bank\%20Umum\%20Konvensional\%20wajib,risiko\%20stratejik\%2C\%20dan\%20risiko\%20kepat uhan.). Diakses 10 Oktober 2020

Peraturan Bank Indonesia. Nomor 15/12/PBI/2013. Tentang Kewajiban Penyediaan Modal Minimum. (Online) (https://www.ojk.go.id/id/kanal/perbankan/regulasi/peraturan-bank-indonesia/Documents/1.pdf). Diakses 10 Oktober 2020.

Permatasari, I., \& Novitasary, R. (2014). Pengaruh Implementasi Good Corporate Governance terhadap Permodalan dan Kinerja Perbankan di Indonesia: Manajemen Risiko Sebagai Variabel Intervening. Jurnal Ekonomi Kuantitatif Terapan, 7(1).

Prasojo. (2015). Pengaruh Penerapan Good Corporate Governance terhadap Kinerja Keuangan Bank Syariah. Jurnal Dinamika Akuntansi Dan Bisnis, 2(1), 59-69. https://doi.org/10.24815/jdab.v2i1.3613

Priyatno, D. (2017). SPSS 22: Pengelolaan Data Terpraktis (A. Prabawati (ed.)). Andi Offset.

Purwanto, W. (2011). Resiko Manajemen Perbankan. Jakarta: CMB Press.

Putri, N., \& Dana, I. (2018a). Pengaruh NPL, Likuiditas, dan Rentabilitas Terhadap CAR Pada BPR Konvensional Skala Nasional di Indonesia. $\quad$ E-Jurnal $\quad$ Manajemen $\quad$ Unud, $\quad 7(4), \quad 1862-1891$. https://doi.org/https://doi.org/10.24843/EJMUNUD.2018.v7.i04.p06

Putri, N., \& Dana, I. (2018b). Pengaruh NPL, Likuiditas, dan Rentabilitas Terhadap CAR Pada BPR Konvensional Skala Nasional di Indonesia. E-Jurnal Manajemen Universitas Udayana, 7(4), $1862-1891$. https://doi.org/10.24843/EJMUNUD.2018.v07.i04.p06

Rehman, M., Rehman, R., \& Raoof, A. (2010). Does Corporate Governance Lead to a Change in The Capital Structure? American Journal of Social and Management Sciences, 1(2), 191-195. https://doi.org/10.5251/ajsms.2010.1.2.191.195

Repi, S., Murni, S., \& Adare, D. (2016). Faktor Faktor yang Mempengaruhi Nilai Perusahaan Subsektor Perbankan Pada BEI Dalam Menghadapi MEA. Jurnal EMBA: Jurnal Riset Ekonomi Manajemen, Bisnis Dan Akuntansi, 4(1). Dari https://doi.org/ttps://doi.org/10.35794/emba.v4i1.11585

Rianto, L., \& Salim, S. (2020). Pengaruh ROA, LDR, NIM, dan NPL Terhadap Capital Adequacy Ratio (CAR). Jurnal Multiparadigma Akuntansi Tarumanagara, 2(3), 1114-1122. https://doi.org/http://dx.doi.org/10.24912/jpa.v2i3.9537

Riyadi, S. (2006). Banking Assets and Liability Management Edisi Ketiga. Lembaga Penerbit Fakultas Ekonomi Universitas Indonesia.

Sari, M., \& Monica, D. (2016). Pengaruh Non Performing Loan (NPL), Loan To Deposit Ration (LDR), Dan Biaya Operasional Terhadap Pendapatan Operasional (BOPO),Terhadap Capital Adequacy Ratio (CAR) Pada Perusahaan Perbankan Yang Terdaftar Di Bursa Efek Indonesia 2010-2015. Jurnal Riset Akuntansi \& Bisnis, 16(1), 71-93. https://doi.org/http://dx.doi.org/10.30596\%2Fjrab.v16i1.1765 
Thoa, P., \& Anh, N. (2017). The Determinants of Capital Adequacy Ratio: The Case of the Vietnamese Banking System in the Period 2011-2015. VNU Journal of Science: Economics and Business, 33(2), 49-58. https://doi.org/10.25073/25881108 /vnueab. 4070

Triyuwono, E. (2018). Proses Kontrak, Teori Agensi dan Corporate Governance. Dari https://www.researchgate.net/publication/322487689_Proses_Kontrak_Teori_Agensi_dan_Corporate_Governance

Tumewu, R., \& Alexander, S. (2013). Pengaruh Penerapan Good Corporate Governance Terhadap Profitabilitas Pada Perusahaan Perbankan yang terdaftar di $\quad$ BEI $\quad$ Periode 2009-2013. https://doi.org/https://doi.org/10.32400/ja.4943.3.1.2014.77-85

Wardiah, M. (2013) Dasar - Dasar Perbankan. Bandung: Pustaka Setia.

Conflict of Interest Statement: The authors declare that the research was conducted in the absence of any commercial or financial relationships that could be construed as a potential conflict of interest.

Copyright (C) tahun terbit nama belakang and nama belakang. This is an openaccess article distributed under the terms of the Creative Commons Attribution License (CC BY). The use, distribution or reproduction in other forums is permitted, provided the original author(s) and the copyright owner(s) are credited and that the original publi-cation in this journal is cited, in accordance with accepted academic practice. No use, distribution or reproduction is permitted which does not comply with these terms. 


\section{LIST OF FIGURES}

1 Conceptual Model

109 


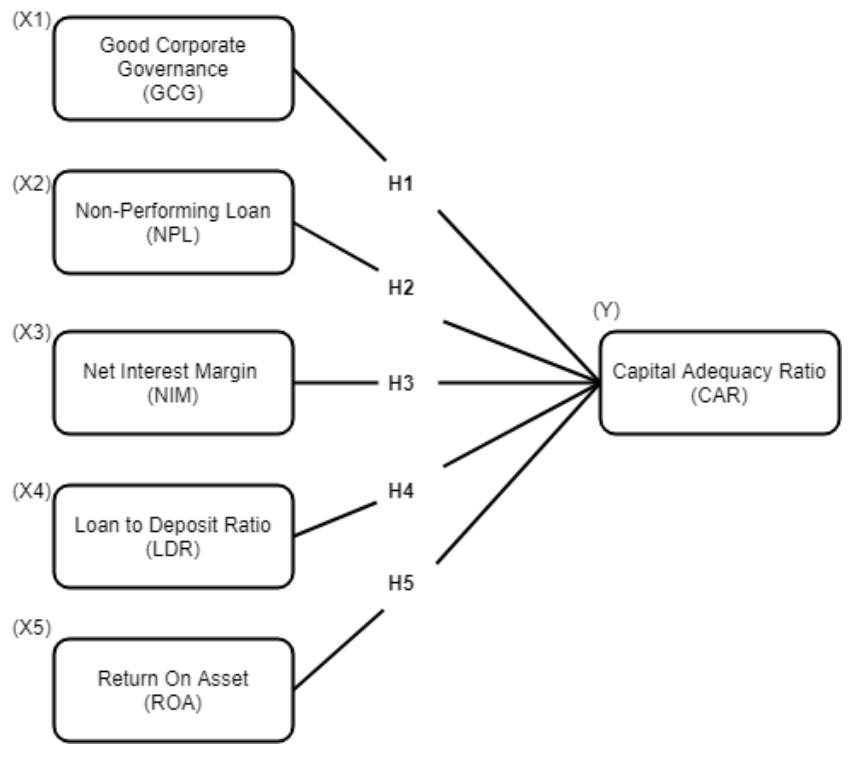

Figure 1 | Conceptual Model 


\section{LIST OF TABLES}

1 Normality and Autocorrelation Test

Multicollinearity and Heteroscedasticity Tests Results.

3 Hypothesis Testing Results 
TABLE 1 | Normality and Autocorrelation Test

\begin{tabular}{lr}
\hline N & Coefficients \\
Test Statistic & 175 \\
Asymp. Sig. (2-tailed) & 0.042 \\
R Square & $.200^{\mathrm{c}, \mathrm{d}}$ \\
Adjusted R Square & 0.027 \\
Durbin-Watson & -0.002 \\
\hline
\end{tabular}

027

2.035 
TABLE 2 | Multicollinearity and Heteroscedasticity Tests Results

\begin{tabular}{llrrr}
\hline & & \multicolumn{2}{c}{ Collinearity } & \multicolumn{2}{r}{ Heteroscedasticity } \\
\cline { 3 - 5 } & & Tolerance & VIF & \multicolumn{1}{c}{ Sig. } \\
\hline 1 & (Constant) & & & 0.185 \\
NPL & 0.95 & 1.052 & 0.687 \\
& GCG & 0.956 & 1.046 & 0.492 \\
ROA & 0.99 & 1.01 & 0.273 \\
LDR & 0.992 & 1.008 & 0.392 \\
NIM & 0.993 & 1.007 & 0.955 \\
\hline
\end{tabular}


TABLE 3 | Hypothesis Testing Results

\begin{tabular}{crrrc}
\hline \multicolumn{2}{c}{ Unstandardized Coefficients } & $\mathrm{t}$ & Sig. \\
\hline 1 & (Constant) & 21.716 & 43.988 & 0.000 \\
NPL & -0.122 & -0.825 & 0.411 \\
& GCG & -0.035 & -0.473 & 0.637 \\
ROA & -0.041 & -0.729 & 0.467 \\
LDR & 0.000 & 0.161 & 0.872 \\
NIM & -0.034 & -1.866 & 0.064 \\
\hline
\end{tabular}

